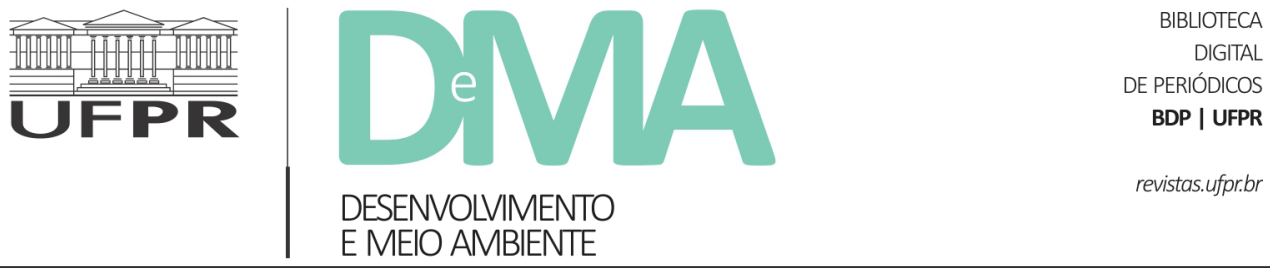

\title{
Pastorais populares e áreas protegidas: a mediação de conflitos no horizonte da Ecologia Política
}

\section{Popular pastorals and protected areas: conflict mediation in the context of Political Ecology}

\author{
Lucas Milani RODRIGUES ${ }^{1 *}$, Marcio Henrique BERTAZI ${ }^{1}$, Victor Eduardo Lima RANIERI ${ }^{1}$ \\ ${ }^{1}$ Universidade de São Paulo (USP), São Carlos, São Paulo, Brasil. \\ *E-mail de contato: rodrigues.milani@gmail.com
}

Artigo recebido em 5 de março de 2020, versão final aceita em 28 de março de 2021, publicado em 7 de outubro de 2021.

\begin{abstract}
RESUMO: $\quad$ Neste trabalho objetiva-se compreender o papel do padre João 30, representante da Pastoral dos Pescadores de Cananéia, São Paulo, enquanto "mediador de conflitos" entre o Parque Estadual Ilha do Cardoso (PEIC) e as comunidades tradicionais que já viviam no território antes da criação daquela Unidade de Conservação. O trabalho está alicerçado na Ecologia Política e metodologicamente balizado pela análise de conteúdo das atas do Conselho Gestor do PEIC, complementada por entrevistas com membros de comunidades caiçaras da Ilha do Cardoso e blog dedicado à trajetória do padre. Os resultados mostram a articulação do clérigo às demandas das comunidades que assistia e revelam seu interesse pela conservação da natureza. Considera-se que a categoria "mediação de conflitos" é um dispositivo relevante no âmbito da Ecologia Política.
\end{abstract}

Palavras-chave: pesca artesanal; conselhos de unidades de conservação; conflitos ambientais; caiçaras; Parque Estadual Ilha do Cardoso.

\begin{abstract}
This paper aims to understand the role of the catholic priest João 30 as a conflict mediator. The priest is a representative of Pastoral dos Pescadores of Cananéia, São Paulo (Brazil) and mediated the problems between Ilha do Cardoso State Park (PEIC) and the traditional communities that already lived in the territory before the Park creation. The work is based on Political Ecology and applied: a content analysis of the PEIC Management Council minutes, interviews with members of the "caiçara" communities in Ilha do Cardoso and a blog dedicated to the priest trajectory. The results disclose the priest's articulation of the community demands and reveal his interest in nature conservation. The category "conflict mediation" is considered a relevant device in Political Ecology.
\end{abstract}

Keywords: artisanal fishing; protected areas councils; environmental conflicts; caiçaras; Ilha do Cardoso State Park. 


\section{Introdução}

$\mathrm{O}$ artigo pretende entender a "mediação de conflitos" realizada pelo Padre João 30 no contexto de criação e implementação de Unidade de Conservação de proteção integral em um território anteriormente ocupado por comunidades tradicionais no litoral paulista ${ }^{1}$. As comunidades em questão são profundamente vinculadas à prática cotidiana da pesca e da agricultura e, repentinamente, por ações políticas, estiveram alijadas das históricas relações com seu local tradicional de reprodução social (Diegues, 1983; Fox \& Callou, 2013; Fox \& Efken, 2019). Por ações políticas entendemos o rearranjo espacial do território em virtude de decisões que desconsideram a demanda da população humana residente, que, como elencado por Pimentel \& Ribeiro (2016), atuam em pelo menos quatro dimensões:(1) institucional, quando diversos níveis e instituições do Estado criam mecanismos de controle do território;(2) econômico, a partir do surgimento de conflitos com relação à normatização do uso dos "recursos" naturais presentes no território;(3) social, que ocorre pela disputa de atores sociais diversos pelo território e (4) cultural, pela ameaça aos saberes locais historicamente consolidados.

$\mathrm{O}$ texto parte de um quadro teórico com o objetivo de situar a possibilidade da "mediação de conflitos" no locus de pesquisa a partir da Ecologia Política. Esta mediação, como se verá, está situada na trajetória de Padre João 30, que transita entre distintas nuances do conflito, entende a relevância de uma Unidade de Conservação (UC) e ao mesmo tempo considera a manutenção das comunidades tradicionais e seus modos de vida. Em sequência, realiza-se uma breve sistematização sobre o Conse1ho Pastoral dos Pescadores e sua atuação no Parque Estadual Ilha do Cardoso (PEIC), bem como sobre os movimentos sociais de pesca. Ao longo do texto também são apresentadas e discutidas as entrevistas realizadas com membros das comunidades caiçaras residentes na Ilha do Cardoso, bem como o material disponibilizado no blog "No meio do Povo", dedicado à memória de Padre João 30 . O objetivo deste artigo é compreender as formas pelas quais Padre João 30 atuou enquanto mediador de conflitos no espaço do Conselho Gestor do Parque Estadual da Illha do Cardoso.

\section{Revisão da literatura}

\subsection{Movimentos sociais e ecologia politica}

Movimentos sociais têm adotado frequentemente um discurso ambiental genérico em suas lutas, além de incorporarem justificativas ambientais para legitimação de sua práxis (Acselrad, 2010). Foi este um fenômeno relevante, sobretudo no Brasil dos anos 1990, cujo cenário de institucionalização do ambientalismo se intensificava (Nobre \& Amazonas, 2002). Parte desses movimentos incorporou uma noção de justiça ambiental que passou a integrar o processo histórico de construção da cultura de direitos humanos e ambientais. A Ecologia Política,

\footnotetext{
${ }^{1}$ Neste trabalho, usamos a seguinte definição de comunidades tradicionais dada pelo Decreto Federal n. ${ }^{\circ} 6.040$ de $2007:$ "Grupos culturalmente diferenciados e que se reconhecem como tais, que possuem formas próprias de organização social, que ocupam e usam territórios e recursos naturais como condição para sua reprodução cultural, social, religiosa, ancestral e econômica, utilizando conhecimentos, inovações e práticas gerados e transmitidos pela tradição" (Brasil, 2007).
} 
nesse sentido, compreende que tal justiça esteja acompanhada da justiça social (Boff, 1996; Martínez-Alier, 2007; Porto-Gonçalves, 2012; Loureiro \& Layrargues, 2013).

A origem dos movimentos sociais coincide com a deslegitimação dos modelos dominantes da realidade (Brulle, 1996). A criação da identidade de um movimento social depende da gênese de novas narrativas que deem conta de um novo arcabouço explicativo de mundo. Nesse sentido, o movimento socioambiental pode ser visto como parte de um movimento de maiores dimensões, que coloca em causa o conjunto de valores da modernidade (Dupuy, 1980). Se tomada a Ecologia Política como a possibilidade de analisar os conflitos ecológicos distributivos (Martínez-Alier, 2007), convém compreender a complexa relação entre natureza e sociedade por meio de análise cuidadosa do acesso e do controle sobre os recursos, além de suas implicações para a sustentabilidade dos meios de existência: trata-se de uma oportunidade de enxergar o conflito - sobretudo o de natureza socioambiental - em termos de luta sobre o conhecimento, o poder e a prática (Elmhirst, 2011), justamente por não fazer sentido a separação entre a política e a natureza (Latour, 2004). Dessa forma, a Ecologia Política pode ser considerada enquanto genealogia das narrativas socioambientais, identificando as diferentes relações de poder suportadas por elas. Tem sido uma alternativa consistente verificar em que medida tais narrativas relacionam-se às políticas de autodeterminação dos povos (Stott \& Sullivan, 2000; Adger, 2001).

Martínez-Alier (1997) identificou que parte significativa dos movimentos sociais que tinham origem na desmedida pobreza estava relacionada com a luta pela sobrevivência e, nesse sentido, eram movimentos ecologistas. Há uma aproximação de Acselrad (2010) na medida em que os objetivos desses movimentos eram definidos pelas necessidades ecológicas para a vida: energia, água, espaço de habitação seguro. Waldman (1988) alertou que a gênese do "problema ambiental" estava atrelada ao fato de a degradação atingir e ultrapassar as fronteiras de classe. Em outro momento, (Waldman, 1994, p. 31) também mencionou a impossibilidade de discutir o meio ambiente com neutralidade, afinal é ele "uma referência concreta de atuação das sociedades ao longo da história, que inventam e reelaboram suas concepções de natureza".

Poderíamos dizer que o movimento socioambiental parte de um processo histórico que tem aglutinado indivíduos e coletivos em torno de concepções muito vastas. Há frequentemente a identificação com processos que, por um lado, valorizam o sentido pleno da vida e, por outro, proponham resgatar um mundo que foi dividido artificialmente (Waldman, 1994). Trata-se de uma afirmação corroborada por Porto-Gonçalves (1990), para quem a complexidade da questão ambiental - e diríamos, socioambiental sem perda de sentido - é o fato de estar inserida na fronteira entre a sociedade e o "seu-outro": a natureza. A herança do pensamento ocidental, que clivou natureza e sociedade, tem sido uma evidente dificuldade. Ainda que a questão ecológica não esteja de todo imune às contradições e barreiras históricas de seu tempo (Waldman, 1994; Leff, 2002; 2018; Pimenta, 2018), parte dos movimentos socioambientais tem apontado para outras possibilidades narrativas na relação entre sociedade e meio ambiente. 


\subsection{CPP-Conselho Pastoral dos Pescadores}

Sader (1995) indicou que a Igreja Católica foi uma importante agência de elaboração discursiva. A matriz discursiva católica procurava fazer da morte (local de egoísmo e comodismo) a vida, a partir de uma ação comunitária em busca da libertação. As Comunidades Eclesiais de Base (CEBs) eram relevantes nesse sentido, por fazerem emergir a "experiência da possibilidade de intervir coletivamente sobre a realidade dada, engatando cada um pessoalmente nesse processo" (Sader, 1995, p. 160). Pastoral popular pode ser definida como um instrumento específico do trabalho da Igreja para ser uma das presenças no universo dos movimentos sociais (Perani, 1989). A Igreja, entendida enquanto uma instituição - produzindo em si mesma as contradições sociais que lhe são historicamente contemporâneas - embora possa ser depreendida enquanto "força social", está longe de ser uma unidade (Seidl \& Neris, 2017). O trabalho pastoral reflete tal desalinho em diferentes nuances: pastoral tradicional (matiz conservadora, enviesada no poder eclesiástico e na dissipação do medo), pastoral moderna ou desenvolvimentista (de tom burguês, cujas raízes emergem da liberdade da consciência via psicologia freudiana) e a pastoral libertadora, que nasce de dentro dos conflitos gerados pelo desenvolvimento do capitalismo a partir da segunda metade do século passado (Libanio, 1982; Dussel, 1999).

A gênese da Teologia da Libertação no contexto latino-americano mostrou a necessidade de compreender a pobreza e a miséria do continente enquanto consequências da injustiça e opressão que marcaram sua história. A incorporação das ciências sociais a um novo modo de se fazer teologia alimentava o arcabouço explicativo de como a riqueza dos países ricos espelhava a transferência de valores e trabalhos dos países pobres (teoria da dependência) (Frank, 1980; Santos, 2000). Essa teologia esteve fortemente influenciada pelo desenvolvimento acelerado do capitalismo, as rápidas e desiguais urbanização e industrialização no continente e pelos ideais e possibilidades da Revolução Cubana, entre 1959-60 (Löwi, 1989). A figura do pobre para esse modo de fazer e pensar a teologia, antigamente objeto de caridade da Igreja, não existia mais enquanto fatalidade (Gutiérrez, 1981), mas como plena de direitos.

No Brasil, as CEBs, que partiam de uma realidade "concreta" para pensar a pedagogia cristã ("ver-julgar-agir"), tornaram-se canais de posicionamento político e desenvolvimento de pautas na luta por direitos (Serbin, 2008). Essa experiência transformava os diferentes movimentos em espaços de socialização política, seja através do aprendizado prático (união, organização, participação, negociação e luta), seja para a construção da identidade social e da apreensão crítica de seu mundo (Grzybowsky, 1991). Entendida como parte relevante na luta social, a pauta ambiental não escapou à alçada das pastorais populares (Boff, 1996).

Exemplo de articulação desta dimensão religiosa é o Conselho Pastoral dos Pescadores. Composto por agentes pastorais, leigos(as), religiosos(as) e padres, foi idealizado pelo Frei Alfredo Schnuettgen, em 1968, em trabalho junto a pescadores(as) de Olinda (PE). Reconhecido em 1976 pela Conferência Nacional dos Bispos do Brasil (CNBB), tornou-se uma instituição com personalidade jurídica em 1988 (Fox \& Efken, 
2019; Ramalho \& Santos, 2020). Comprometido com as demandas dos(as) pescadores(as) artesanais, o CPP pode ser analisado sob a figura de Jan van der Heijden, conhecido como padre João 30 por moradores(as) da região de Cananéia, litoral sul do estado de São Paulo.

Padre João 30 tomou posse como pároco de Cananéia em 16 de junho de 1974 e desde então passou a residir em definitivo no município. A memória coletiva registra sua dedicação à Paróquia de São João Batista e seu profundo interesse em Cananéia e na realidade do povo caiçara. Recorrentemente Padre João é lembrado carinhosamente por ter feito questão de morar em Cananéia, local em que viveu metade de sua vida, de 1974 a 2006. Quando se aposentou em maio de 2006, mudou-se para o bairro do Carijo, local em que criou um espaço comunitário para continuar atuando em questões ambientais e dos(as) pescadores(as) artesanais e pequenos(as) agricultores(as) (No Meio do Povo, 2011).

\subsection{Movimentos sociais e pesca}

Ao se olhar para o espaço da pesca artesanal, é essencialmente um espaço de identidade, pertencimento, respeito e conhecimento dos locais que foram historicamente ocupados. Enquanto apropriação material e social de recursos, a pesca, como aponta Diegues (1983, p. 7), "coloca problemas relevantes na análise da relação entre o homem e a natureza". Também já foi mencionada a capacidade de resiliência da pesca artesanal em reajuste rápido às mudanças climáticas (Silva, 2014), muito embora essa capacidade não tenha sido a mesma em outros processos históricos de ameaça e concretização de expulsões. Trata-se de um "território" quando pes- cadores(as) artesanais apropriam-se destes espaços (Rios, 2016) e ali constroem suas vidas. Segundo Jatobá et al. (2009, p. 77), território em Ecologia Política é "uma construção política resultante da interação de forças entre atores com capacidades desiguais de poder e objetivos por vezes antagônicos". São estes territórios transformados em epicentros de conflitos quando outras demandas - de natureza diversa das do espaço tradicional - procuram ocupá-lo, frequentemente aproveitando-se das assimetrias de poder. É o espaço de pesca brasileiro local histórico de conflitos e disputas socioambientais: do turismo à pesca comercial, da especulação imobiliária às práticas preservacionistas (Tomás \& Santos, 2016). Ainda assim, cerca de $70 \%$ da produção de pescado no Brasil é oriunda da pesca artesanal (Conselho Pastoral dos Pescadores, 2017).

Em recente relatório da Food and Agriculture Organization of the United Nations (FAO), o Brasil foi apontado como o $18^{\circ}$ produtor de pescado do mundo, com mais de um milhão de trabalhadores(as) diretamente envolvidos(as) na pesca e outros(as) três milhões envolvidos(as) indiretamente. Enquanto $60 \%$ da captura nacional vem da pesca em pequenas escala, $65 \%$ da produção brasileira tem como origem a pesca marinha e estuarina. $\mathrm{O}$ documento aponta como "fatores de pressão" na atividade pesqueira a perda e degradação de habitat, a pesca ilegal e a pressão oriunda da pesca industrial (Mattos et al., 2020).

Fox \& Callou (2013) apontam que, embora até o início dos anos 1980 tenha havido algum silêncio acadêmico sobre os movimentos sociais de pescadores e pescadoras no Brasil, existem registros bem anteriores de diferentes demandas por parte dessa população. Nos anos 1960, por exemplo, mobilizações de pescadores(as) em Per- 
nambuco reagiam à poluição causada pelas usinas de cana-de-açúcar e outras indústrias que estavam degradando o ambiente de seu trabalho. Nos anos 1970, com a mediação do CPP, outras pautas foram trazidas à tona, como a reivindicação dos direitos previdenciários, luta contra expulsão das praias, preço dos insumos e valor pago por intermediários, linhas de crédito, etc. Seja como for, os movimentos sociais de pescadores(as) artesanais são processos políticos e sociais construídos como expressões de luta coletiva e de resistência. Há nesse processo o desenvolvimento e fortalecimento de uma identidade coletiva que busca garantir o acesso aos recursos naturais presentes em seus territórios. Naturalmente este processo ocasionou também uma valorização do extrativismo e dos sistemas de produção alternativos. As comunidades pesqueiras são híbridas e multifacetárias, nomeadamente onde a pesca artesanal convive com outras relações, como o turismo, o artesanato, a indústria. Frequentemente há um convívio entre a tradição e a modernidade (Diegues, 1983; Ramalho, 2011; 2015).

$\mathrm{Na}$ linha destas manifestações sociais, o Movimento dos Pescadores e Pescadoras Artesanais do Brasil (MPP) configurou-se como ação social coletiva de luta e de resistência. Tal movimento foi reconfigurado sobre as bases da Associação do Movimento Nacional dos Pescadores (AMONAPE), que representou o grupo entre 1990 e 2009. O MPP pretende a garantia de proteção do território pesqueiro, além do modo de vida e da produção característicos de culturas tradicionais (Fox \& Efken, 2019).
Sendo assim, é importante observar que ao estabelecimento histórico destas populações corresponde o aperfeiçoamento de sabedoria própria da práxis, que não diz respeito apenas ao manuseio de algo, mas onde, como e quando aplicá-lo (Rios, 2016). Como já observava Simondon ([1969] 2018), o objeto técnico tem valor intrínseco, pois concretiza-se na prática humana como um análogo dos objetos naturais: processo de profunda inventividade. A abrupta interrupção deste processo consiste numa das mais evidentes disparidades de poder e instauração de violência. A América Latina tem sido um laboratório producente para a Ecologia Política, porque a cultura e a natureza presentes no território são lidas através das relações de poder: o Estado-Nação tem abrigado um "colonialismo interno" que tende a ignorar ou matizar as múltiplas territorialidades no interior do Estado (Porto-Gonçalves, 2012).

\subsection{Conflitos em unidades de conservação}

Unidades de Conservação (UC) são locais de riqueza natural e cultural (Dudley, 2008²). Quando uma UC é criada sem levar em conta as demandas dos povos que tiveram seu território sobreposto, há mais do que uma disputa legal: há uma inversão de valores culturais. Nesse sentido, um verdadeiro movimento de "refugiados da conservação" (Dowie, 2006) somava as filas de expulsos do sistema capitalista (Sassen, 2016). Tais populações, que já eram escamoteadas política e economicamente, também

\footnotetext{
${ }^{2}$ No Brasil esses territórios são geridos com base na Lei Federal n ${ }^{\circ} 9.985$ de 2000, conhecida como Lei do SNUC - Sistema Nacional de Unidades de Conservação. Dentro das categorias de UC previstas na lei federal existem os Parques, cujos objetivos estão ligados à conservação de biodiversidade in situ e à preservação da beleza cênica (Brasil, 2000; 2002).
} 
viam ameaçadas suas atividades culturais. Suas ações de manejo tornam-se incompatíveis aos novos objetivos do espaço. Corresponde a este processo o agravamento das condições de vida das comunidades envolvidas e a possível expulsão das populações tradicionais de seus territórios (Arruda, 1997). Este tipo de conservação se utiliza da narrativa colonizadora e pode transformar populações historicamente independentes em comunidades profundamente dependentes e empobrecidas (Dowie, 2006).

Martínez-Alier (2007) denomina como "culto à vida silvestre" a ideia de um território natural intocado que deve ser preservado. Arruda (1997) defende que esse tipo de abordagem preservacionista baseada em modelo estadunidense se mostra ineficaz na América Latina, Ásia e África. Para Colchester (2000), essa construção de mundo selvagem não é compartilhada por povos que possuem outro tipo de relação com o que é chamada pela sociedade ocidental de natureza. Devido a essa diferença de percepção do território, Brockington et al. (2008) propõem que formas de gestão destes territórios precisam ir além de uma regra universalizada. Para estes últimos autores, as características locais e a aproximação e voz às comunidades tradicionais são essenciais à conservação.

Conflitos que ocorreram pela criação de áreas protegidas observando-se critérios preponderantemente "ecológicos" em detrimento de critérios sociais (i. e., enxergando a sociedade como "externa" àquele meio) são fartamente reportados ao redor do mundo, incluindo o Brasil. Especificamente na região do Vale do Ribeira, no estado de São Paulo, Ferreira (2004) mostrou as relações estabelecidas entre orientações políticas estaduais para gestão de UC e as comunidades locais. Prado \& Nunes (2005) destacaram os impactos negativos ao modo de vida da população local a partir da criação, em 1986, da Estação Ecológica da Juréia, também no Vale do Ribeira. Ainda na mesma região, Silva (2012), ao analisar o Mosaico do Jacupiranga (MOJAC) ${ }^{3}$, aponta que mesmo um processo que aparentemente pretendia devolver às comunidades tradicionais seu território poderia ser excludente, devido aos zoneamentos das UC.

\section{3. Área de Estudo: Parque Estadual Ilha do Cardoso-PEIC}

A Ilha do Cardoso foi transformada em Parque Estadual em 1962 com a justificativa de proteger sua importante biodiversidade, com destaque para o fato de $95 \%$ de sua área estar coberto por vegetação nativa (Mata Atlântica). Quanto aos residentes, o decreto de criação do Parque determinava a necessidade de desapropriação de suas terras (São Paulo, 1962). Rodrigues (2001) traz que a população da Ilha do Cardoso, na ocasião da criação do Parque, era principalmente formada por comunidades caiçaras. Também havia nessa época um pequeno grupo composto por veranistas que, na década de 1950, instalaram-se em um loteamento na ilha. Os indígenas Guarani Mybia ${ }^{4}$ chegaram à região na década de 1990 e estabeleceram sua aldeia na Ilha do Cardoso. A Figura 1 mostra a localização aproximada das sete comunidades caiçaras no Parque (outubro de 2018).

\footnotetext{
${ }^{3}$ Compõem o Mosaico 14 UC. Ver mais em: < https://www.saopaulo.sp.gov.br/sala-de-imprensa/release/mosaico-de-unidades-de-conservacao-do-jacupiranga-completa-10-anos/>. Acesso em: jul. 2020.

${ }^{4}$ Atualmente a Terra Indígena Pakurity (Ilha do Cardoso) encontra-se identificada. Ver mais em: $<$ https://terrasindigenas.org.br/pt-br/terras-in-
} 


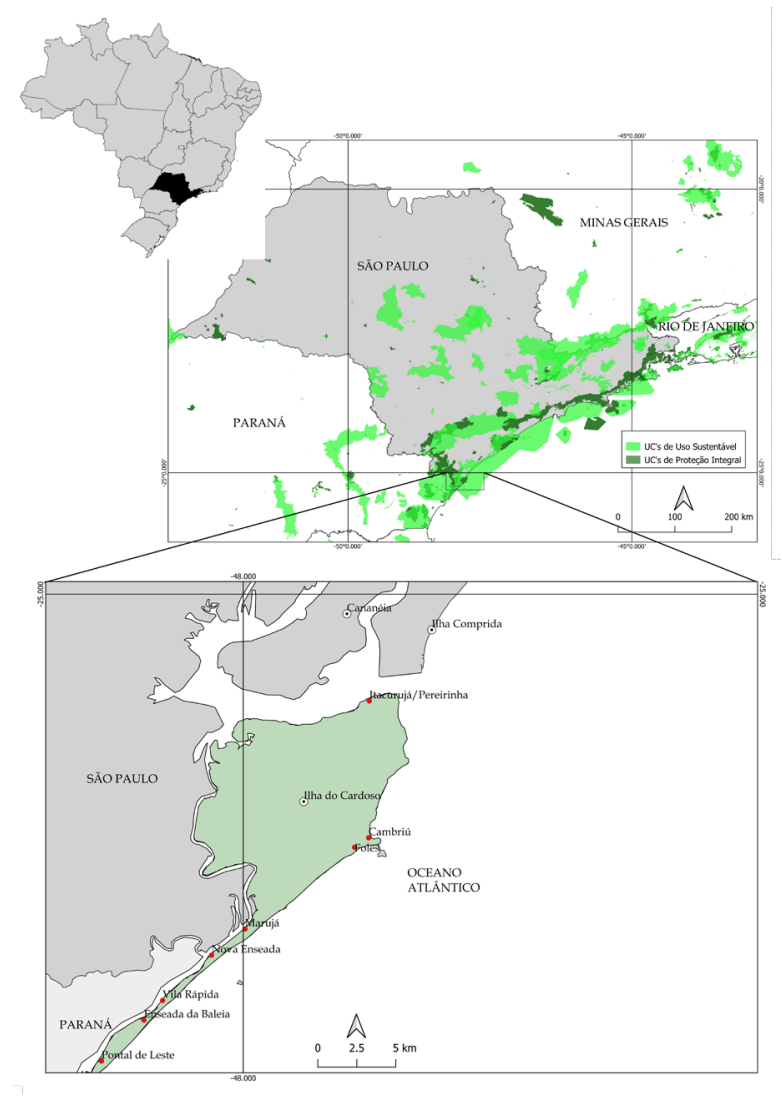

FIGURA 1 - Localização das sete comunidades caiçaras residentes no Parque Estadual Ilha do Cardoso: Itacuruça/Pereirinha, Cambriú, Foles, Marujá, Enseada da Baleia (Nova Enseada) ${ }^{5}$, Vila Rápida ${ }^{6}$ e Pontal de Leste.

FONTE: IBGE (2019); i3geo (2019); Google Earth (2019). Montagem dos mapas: autores.
Diegues (1988) elucida que caiçaras são as populações litorâneas que vivem em pequenos povoados nos estados do Paraná, São Paulo e Rio de Janeiro. Sua prática é a pesca artesanal, agricultura e coleta. Adams (2000) complementa que, no passado, as populações caiçaras eram majoritariamente lavradores-pescadores. Apesar dessas características, a autora aponta que uma caracterização única do caiçara não seria possível, visto que as comunidades possuem diferenças entre si.

Quanto à Ilha do Cardoso, o Plano de Gestão Ambiental do Parque foi construído no Conselho Gestor, instância responsável por avanços no gerenciamento do território (Rodrigues, 2001). Os Conselhos são espaços de relativa aceitação para se pensar formas de gestão e diálogo entre vários setores (organizações não governamentais, as próprias instituições do governo e, claro, a população envolvida). Estes espaços, entretanto, não garantem por si mesmos a participação e democracia. Loureiro \& Cunha (2008) sugerem a possibilidade de manipulação, de excesso burocrático, reduzida autonomia, linguagem não acessível a todos(as) os(as) participantes e a não disponibilização de informações estratégicas. Nesse sentido, como situado acima por Dowie (2006), muitas Unidades de Conservação foram criadas com pouca participação social, e isso está relacionado a um sentido de pertencimento muito baixo, sobretudo

digenas/5171>. Acesso em: out. 2019. Rodrigues (2001, p. 90) traz que a questão da Terra Indígena foi um debate intenso na gestão do PEIC. Apesar da importância do tema, o foco do artigo é sobre a participação do CPP. De todo modo, sinalizamos como um tópico de possibilidade de aprofundamento para pesquisas futuras.

${ }^{5}$ Até o ano de 2018 a Enseada da Baleia localizava-se entre a Vila Rápida e o Pontal de Leste. Devido à abertura de uma nova barra, e consequente "divisão" da ilha em duas partes, a comunidade da Enseada da Baleia transferiu-se para próximo do Marujá, e o novo local passou a receber o nome de Nova Enseada. O processo de realocação é descrito em Yamaoka et al. (2019).

${ }^{6}$ Em uma live comemorativa de aniversário do Parque Estadual Ilha do Cardoso, foi mostrado que a Vila Rápida também precisou mudar-se devido a nova barra já ter atingido o antigo local da comunidade. Ver em: $<$ https:/www.youtube.com/watch?v=1HUev19ecJY $>$. Acesso em: jul. 2020. 
da população que por ventura teve seu território absorvido por estas unidades (Loureiro et al., 2007). Sessin-Dilascio (2014) aponta a Ilha do Cardoso como um exemplo de território de cogestão, visto que há na evolução da dinâmica do Conselho Gestor um envolvimento entre os diversos atores sociais. Schröter et al. (2014) concluem que o exemplo da Ilha do Cardoso pode referenciar a importância da organização interna das comunidades na gestão de território. Este envolvimento, evidentemente, não esteve alheio a conflitos frequentes entre as partes envolvidas. Embasado no referencial teórico da ecologia política e movimentos sociais, este artigo aborda o papel do padre João 30 , do CPP, enquanto "mediador de conflitos" entre atores que, com a criação da UC, passaram a disputar o mesmo território.

\section{Metodologia}

Metodologicamente, a construção do artigo esteve alicerçada em pesquisa documental com dados secundários (Sá-Silva et al., 2009; Uwe, 2009) e análise de conteúdo (Bardin, 2011). Os dados secundários foram atas das reuniões do Conselho do Parque Estadual da Ilha do Cardoso realizadas entre 25 de março de 1998 (data da primeira reunião do Conselho e que contou com a participação do $\mathrm{CPP}$ e 29 de junho de 2010 (última reunião com participação de um representante da entidade). Entendemos como "participação do CPP" o registro em ata de presença de representante da Pastoral na reunião do Conselho. No período em questão, refere-se majoritariamente às participações do Padre João 30 (nove anos e seis meses) e, ao final, do padre Victor (dois anos e dois meses).

Além de verificar a participação (por meio da tabulação de nomes) de todas as pessoas e instituições que estiveram presentes nas reuniões, também foi realizada análise de conteúdo dos posicionamentos do CPP. Estes posicionamentos foram organizados em seis categorias determinadas a priori (Bardin, 2011), descritas na Tabela 1.

Martins \& Theóphilo (2009) argumentam que a triangulação de dados possibilita maior confiança em uma pesquisa. Desta forma, o presente trabalho fez uso de mais duas fontes de pesquisa além das atas. Em primeiro lugar, foram realizadas entrevistas $^{7}$ com membros das comunidades caiçaras da Ilha do Cardoso, em outubro de 2018, pouco mais de dez anos após a morte de Padre João 30, ocorrida em 17 de março de 2008 (Moaes, 2013). Cabe destacar que os(as) entrevistados(as) são identificados(as) de acordo com comunidade de morada (Itacuruça/ Pereirinha 01 e 02 e Marujá 04), sem atribuir-lhes gênero ou qualquer outra informação que possa identificá-los(as). Todos(as) os(as) entrevistados(as) assinaram termo de consentimento prévio livre e esclarecido.

Em segundo lugar, foram consideradas informações disponibilizadas no blog "No Meio do Povo". O blog, que teve início em março de 2011, é dedicado exclusivamente à memória do Padre João 30. O conteúdo do site foi relevante na memória que

\footnotetext{
${ }^{7}$ As três pessoas fazem parte de um conjunto de 22 entrevistadas no âmbito de uma pesquisa mais ampla sobre turismo e comunidades caiçaras na Ilha do Cardoso. Das 22 entrevistas, apenas três fizeram menção ao Padre João 30 e, por este motivo, os relatos dessas pessoas foram utilizados como fonte para a elaboração deste artigo.
}

${ }^{8}$ Site: <http://nomeiodopovo.blogspot.com/>. Acesso em: out. 2019. 
as comunidades tradicionais de caiçaras da região se lembravam de sua figura. Aparecem ações cotidianas de João 30, inclusive textos e posicionamentos de sua autoria frente aos conflitos que ocorriam entre as comunidades tradicionais e o PEIC. Tanto as entrevistas quanto o blog não foram verificados estruturalmente pelas categorias de análise de conteúdo. Esses dados colaboraram na discussão de modo complementar a essas categorias construídas a priori no método.

\section{Resultados e discussão}

\subsection{Panorama de participação do CPP no conselho do PEIC}

Das 139 reuniões do conselho do PEIC que aconteceram de 1998 a 2010, a Pastoral dos Pescadores de Cananéia esteve presente em 64, ou seja, $46 \%$ dos encontros. Das 45 instituições da sociedade civil $^{9}$ que estiveram presentes nessas reuniões, a

TABELA 1 - Categorias a priori de análise de conteúdo.

\begin{tabular}{lll}
\hline Categorias a priori & Descrição \\
\hline Conciliação & $\begin{array}{l}\text { Classificou-se como conciliador todo posicionamento do CPP que tentasse resolver uma questão, indepen- } \\
\text { dente de qual assunto fosse, atentando-se a atender às regras construídas no Parque, mas também aos direitos } \\
\text { das comunidades tradicionais. }\end{array}$
\end{tabular}

Conselho PEIC

Todos os posicionamentos do CPP que colaboraram para estruturação do Conselho do PEIC, seja em sua organização interna ou participação em reuniões extras para discutir formas de gestão do Parque, não ficando clara a defesa direta dos moradores tradicionais.

Defesa das Comunidades

Falas que defendem os interesses das comunidades caiçaras e povos indígenas em contraposição aos interesses do Parque, principalmente em defesa de seus modos de vida e acesso a bens públicos, como água, luz, etc. Tais falas podem, inclusive, estarem em oposição às demandas do Parque.

\begin{tabular}{ll}
\hline Pró Igreja & $\begin{array}{l}\text { Afirmativas que tiveram o intuito de valorizar a Igreja dentro deste espaço de discussão que é o Conselho } \\
\text { Consultivo do PEIC. }\end{array}$ \\
\hline Posicionamentos da pastoral que pudessem ser contrários aos interesses das comunidades. Difere do conceito \\
de conciliação, pois na categoria conciliação há uma tentativa da pastoral de dialogar com as perspectivas \\
diferentes. Nesta categoria estão os posicionamentos da pastoral que se opõem aos direitos do modo de vida \\
das comunidades caiçaras e indígena.
\end{tabular}

Neutro

Refere-se a falas que sejam avisos, dúvidas, ou colocações que não sejam imbuídas de uma significação relevante à pesquisa

FONTE: Elaborado pelos autores.

${ }^{9}$ Sociedade Civil refere-se aos grupos da sociedade que não vivem na Ilha do Cardoso. Essa classificação foi feita pelos autores do artigo e não constava nas atas. 
Pastoral ocupou a terceira posição em frequência. Das participações da Pastoral, O Padre João 30 representou a Pastoral em 58 das 64 participações da entidade, durante o período de 1998 a 2007, dado que deixa claro sua relevância dentro do CPP e do Conselho do PEIC. As presenças em número absoluto foram distribuídas conforme a Tabela 2 apresenta.

Cabe destacar, ainda, que a última reunião do conselho em que o Padre João participou foi em 12 de setembro de 2007. A Pastoral dos Pescadores continuou participando por mais três anos ${ }^{10}$. No entanto, a frequência de participação foi menor.
Enquanto Padre João 30 esteve ativo na CPP, apenas nos anos de 1999 e 2001 houve uma baixa participação da instituição. A partir dos dados coletados, não é possível tecer uma hipótese do porquê essa participação foi menor nesses dois anos. Destaca-se que, após o afastamento do clérigo a Pastoral ainda participou do Conselho do Parque, mas com acentuada queda de presença nos encontros. Em 2010 a pastoral teve sua última participação e, desde então, não interage mais nesse espaço de discussão. Esta diminuição gradativa, como notada por Ramalho \& Santos (2020), pode estar relacionada a um arrefecimento geral nos movimentos sociais a partir

TABELA 2 - Presença da Pastoral e Padre João 30 no Conselho do PEIC entre 1998 e 2010.

\begin{tabular}{cccc}
\hline Ano & Total de reuniões & Presença da Pastoral & Representadas pelo Padre João 30 \\
\hline 1998 & 11 & 07 & 07 \\
1999 & 16 & 03 & 02 \\
2000 & 09 & 06 & 06 \\
2001 & 10 & 01 & 01 \\
2002 & 09 & 06 & 06 \\
2003 & 11 & 06 & 06 \\
2004 & 09 & 06 & 06 \\
2005 & 14 & 09 & 09 \\
2006 & 16 & 10 & 10 \\
2007 & 08 & 05 & 05 \\
2008 & 07 & 02 & 00 \\
2009 & 12 & 02 & 00 \\
2010 & 07 & 01 & 00 \\
TOTAL & $\mathbf{1 3 9}$ & $\mathbf{6 4}$ & $\mathbf{5 8}$ \\
\hline
\end{tabular}

FONTE: Dados da pesquisa.

\footnotetext{
${ }^{10} \mathrm{Na}$ ata da reunião de 13 de julho de 1999, consta Maria Aparecida Rangel representando o CPP no lugar de Padre João 30 . A partir da ata não é possível definir qual o vínculo da participante com o CPP. Infere-se que trabalhava junto ao Padre João 30 na pastoral de Cananéia. Em 2008 e 2009, as participações foram do Padre Victor Hernandez Rodriguez, que veio substituir o Padre João 30. Em 2010 houve uma única participação de Laerte Barbosa representando o CPP. Infere-se que este trabalhava na Pastoral de Cananéia junto ao Padre Victor.
} 
da década de 1990 e que parece não ter descolado da realidade dos pescadores e das pescadoras artesanais. Nos anos 1990, o CPP experimentou uma crise interna de organização, o que influenciou sua capacidade enquanto rede de articulação (Fox \& Callou, 2013). É curioso, entretanto, que, no caso aqui analisado, enquanto o Padre João 30 esteve à frente do CPP em Cananéia, tenha-se notado elevada articulação nos anos em que se nota uma diminuição desses movimentos em outros lugares do país.

\subsection{Os Posicionamentos de Padre João 30 e CPP no PEIC}

A análise qualitativa das manifestações da Pastoral dos Pescadores no Conselho do PEIC (1998-2010) a partir das categorias a priori inferiu 81 posicionamentos no período selecionado. Destes, apenas dois não são de Padre João 30. A distribuição destes posicionamentos está condensada na Tabela 3.

TABELA 3 - Posicionamentos por categorias de análise das atas do PEIC.

\begin{tabular}{ccc}
\hline Categoria & Quantidade & $\mathbf{\%}$ \\
\hline $\begin{array}{c}\text { Conciliação } \\
\text { Defesa das comu- } \\
\text { nidades }\end{array}$ & 36 & $44 \%$ \\
Conselho PEIC & 29 & $36 \%$ \\
Pró Igreja & 12 & $15 \%$ \\
Neutro & 02 & $2,5 \%$ \\
TOTAL & 02 & $2,5 \%$ \\
\hline
\end{tabular}

FONTE: Dados da pesquisa.
Esses dados nos mostram que, nos doze anos de atuação no Conselho do PEIC, a Pastoral dos Pescadores, especialmente representada por Padre João 30 , nenhum de seus posicionamentos enquadram-se na categoria "contra as comunidades" presentes na Ilha do Cardoso. Nota-se também que posicionamentos pró Igreja Católica ocorreram com baixa frequência (dois momentos no início do Conselho, em 1998). Naquele ano, requisitou-se a construção de uma capela na Comunidade Caiçara Pontal de Leste. Posteriormente, em outra reunião, a necessidade de coletar as assinaturas de todos(as) da comunidade consentindo com tal construção.

Dos dois posicionamentos considerados "neutros", enumera-se: (1) em 2005, quando Padre João 30 avisou que estaria fora da cidade de Cananéia por dois meses e (2) em 2008, quando Padre Victor foi nomeado como conselheiro da pastoral no PEIC, após a morte de Padre João 30.

As categorias conciliação, defesa das comunidades e conselho do PEIC, somadas, representam 95\% dos posicionamentos da Pastoral dos Pescadores nas reuniões. Na Figura 2, apresenta-se a distribuição da quantidade desses posicionamentos ao longo dos anos.

Foi 1998 o ano em que a Pastoral dos Pescadores mais se fez notar junto ao Conselho, provavelmente por ser o início desse espaço de discussão. A categoria "defesa das comunidades" não esteve presente apenas no ano de 2001, ano em que houve uma baixa participação da Pastoral.

Em relação à categoria Conselho do PEIC (1998-2010), fica claro que apenas no início do período houve maior quantidade de posicionamentos nesse sentido. O Conselho do PEIC, apesar de teoricamente consultivo, funcionou em caráter deliberativo principalmente pela postura do gestor 
da época em que essa instância começou a se reunir (Rodrigues, 2001). Tal postura certamente influenciou que os representantes se dedicassem à gestão. Especificamente em relação ao bom funcionamento do Conselho do Parque, percebe-se que havia, de fato, uma preocupação da Pastoral em torná-los cada vez mais representativos. Logo no início do Conselho, em 1998, a pastoral sugeriu, inclusive, a criação de associações de bairros informais para contemplar as comunidades afetadas pelo Parque. Um importante posicionamento de Padre João 30, no mesmo ano, foi a proposta de repensar a participação de pessoas "de fora" nas reuniões do
Conselho, pois isso poderia tirar a liberdade dos(as) participantes. Realizou também um pedido para oficializar a participação da Câmara Municipal de Cananéia, diante de suas recorrentes ausências nos encontros em $2002^{11}$. Outra preocupação da pastoral foi de se colocar à disposição em reuniões paralelas às reuniões do Conselho. Em 2004, por exemplo, participou de um grupo de discussão sobre o Plano de Manejo ${ }^{12}$ e também do encontro para definir as regras de uso do território pelos(as) moradores(as) tradicionais. Além desta disposição em participar dos encontros paralelos, há relatos nas atas do Padre João 30 frisar a importância do registro em atas dos

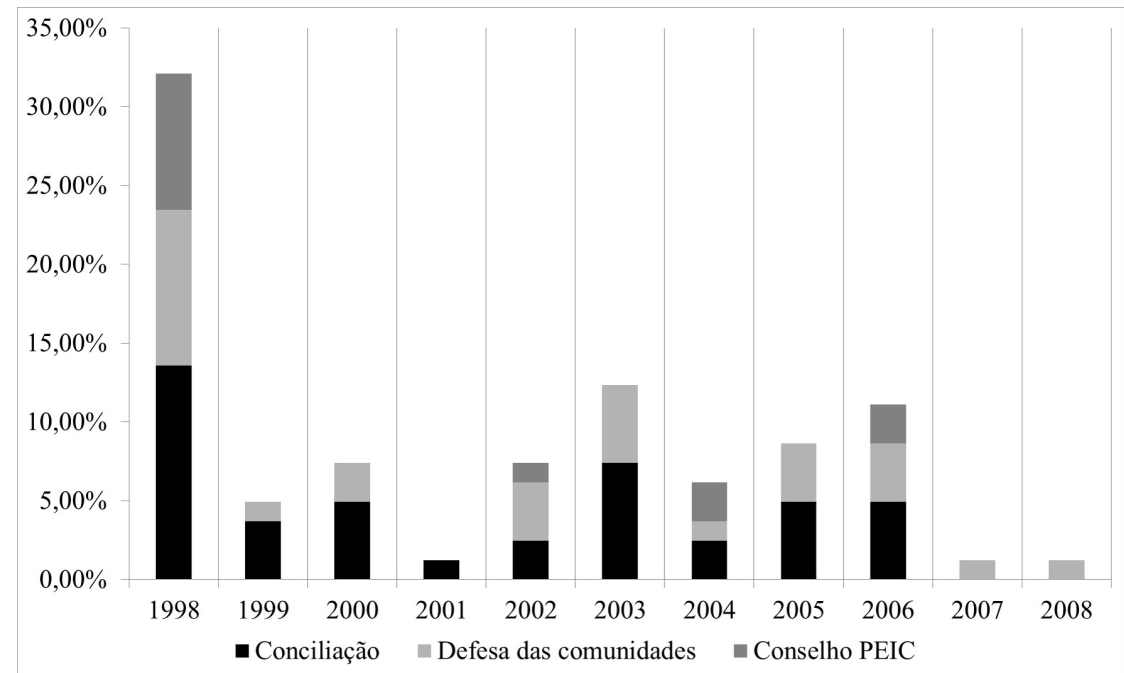

FIGURA 2 - Categorias de análise ao longo dos anos (\%)

FONTE: Dados da pesquisa.

\footnotetext{
${ }^{11}$ É interessante destacar que no ano de 1999 o CPP também recebeu um ofício para que se posicionasse sobre sua baixa participação (ata de 13/12/1999). No ano seguinte, a presença do CPP foi muito maior. Ou seja, uma articulação do Conselho que já teria tido efeito até mesmo sobre o CPP.

12 "Documento técnico mediante o qual, com fundamento nos objetivos gerais de uma unidade de conservação, se estabelece o seu zoneamento e as normas que devem presidir o uso da área e o manejo dos recursos naturais, inclusive a implantação das estruturas fỉsicas necessárias à gestão da unidade" (Brasil, 2000, art. 2). Tal documento orienta a gestão de uma UC.
} 
encontros logo no início do Conselho, em 1998, e também oferecer o salão paroquial para encontros paralelos às reuniões do Conselho, caso necessário. Além disso, seu trabalho foi reconhecido dentro do PEIC (1998-2010), como em 2005, na discussão sobre organização das atividades internas onde, por unanimidade, os participantes o nomearam como vice coordenador do Conselho.

Sobre a defesa das comunidades, segundo o blog em sua homenagem, quando foi criado o PEIC e as ordens de retirada da população tornaram-se uma realidade iminente, Padre João lembrava-se do poder simbólico da Polícia Florestal ao perseguir a população que tinha roças na área. A tradição de roçada e queimada, sobretudo em agosto e novembro, trazia consigo o temor de que houvesse multas e outras medidas judiciais, até então desconhecidas para essas populações. O Estado lhes aparecia apenas enquanto força coercitiva. Esse tipo de conflito fazia com que as pessoas abandonassem a pequena agricultura e se mudassem em direção à cidade (No Meio do Povo, 2011). A resistência das comunidades e a ajuda do Padre Joao 30 neste contexto é rememorada pelos entrevistados da comunidade do Itacuruça/Pereirinha. Relatam que em 1986 houve uma tentativa de retirada da comunidade, e foi por meio da intervenção do sacerdote que essa intervenção não teve sucesso.

A defesa das comunidades no Conselho do PEIC (1998-2010) o Padre João 30 manifestou de muitas formas. A principal delas foi a valorização histórica e cultural das comunidades presentes no Parque Estadual Ilha do Cardoso. No início do Conselho, em 1998, Padre João 30 argumentou em favor das roças de mandioca, prática que faz parte da tradicional cultura caiçara, conforme consta nas atas deste ano. Além disso, destacou a importância de resgatar o histórico da cachoeira da máquina, local próximo à comunidade do Cambriú, como forma de valorizar a história local. Em 2004 o recém-eleito prefeito de Cananéia esteve presente na reunião do Conselho, e o Padre João 30 fez questão de destacar a importância das comunidades da Ilha do Cardoso para o município, além de cobrar de sua gestão uma melhoria na arquitetura da cidade, o que demonstra também preocupação com a cultura material do município e seus possíveis desdobramentos junto às populações, como o investimento no turismo. Um exemplo de sua defesa se deu na ata de número 14 , datada de 12/03/1999, quando o coordenador do Conselho trouxe algumas regras para a pesca de cerco fixo ${ }^{13}$, as quais Padre João entendeu como inapropriadas, conforme se lê no trecho reproduzido: "Segundo Padre João 30, entendeu que de acordo com as normas impostas pelo coordenador do comitê, a respeito do assunto, é a mesma coisa que dizer ao pescador tradicional que é proibido pescar".

Observa-se também a posição contrária às grandes empresas de pesca. Em 1998 Padre João 30 destacou que a fiscalização deveria acontecer de forma mais efetiva com esse setor, em comparação com a atividade do(a) pescador(a) artesanal. Em 2002, durante discussão sobre a Estação Ecológica Tupiniquim, UC também de proteção integral e vizinha à Ilha do Cardoso, os(as) presentes debateram formas de proibição de pesca ao redor da área. Padre João 30 afirmou que o que deveria ser

\footnotetext{
${ }^{13}$ Trata-se de cercas fixas que funcionam como armadilhas para os cardumes que passam pelos canais na região lagunar de Cananéia-lguape (Ramos et al., 1980).
} 
feito era aumentar a fiscalização, principalmente de grandes barcos de pesca, em vez de se coibir uma atividade tradicional.

A sua práxis enquanto mediador de conflitos tornava visível, a todo o momento, o registro e interpretação das diferentes querelas que ocorriam entre as comunidades que assistia e o PEIC. Via como necessário elencar os motivos pelos quais tais populações, frequentemente empobrecidas, tinham de lutar "até contra ambientalistas" (No Meio do Povo, 2011), para defender o território onde historicamente viviam.

Essa postura de enfrentamento aparecia quando Padre João 30 considerava que as propostas tinham caráter impositivo, algo que ocorreu, por exemplo, em três momentos do ano 2000. Um deles foi a chegada de ordens do diretor do Instituto Florestal, órgão gestor das Unidades de Conservação estaduais à época. Dentre estas ordens, havia uma em que se proibia a construção de edificações em Estações Ecológicas e Parques, pautada na Resolução do Conselho Estadual de Meio Ambiente de 14/12/1995 (Consema, 1995), que trata especificamente das normas de construção na Ilha do Cardoso. Padre João sugeriu que fosse revisto esse posicionamento para que as comunidades tradicionais não fossem prejudicadas. Outro momento foi o questionamento do Sistema Nacional de Unidades de Conservação (SNUC), na reunião 08 de agosto de 2000, recém-votado na ocasião e promulgado como Lei. Posicionou-se dizendo que o SNUC não abordava como deveria o contexto cultural dos Parques, e o caso do PEIC seria emblemático neste sentido. Cabe notar que o posicionamento do Padre João 30 é coerente com o que Santilli (2005) verificou sobre a necessidade de combinar aos direitos das comunidades tradicionais à garantia dos direitos culturais territoriais, algo semelhante ao que apontou Acselrad (2010) sobre a incorporação de justificativas ambientais na legitimação da práxis social. Posteriormente, em 2005, foi aprovado o Projeto do Desenvolvimento do Ecoturismo na Região da Mata Atlântica pelo governo do estado de São Paulo ${ }^{14}$. Este foi apresentado aos(às) participantes, e uma de suas intenções era de realização de "pequenas concessões", em vez de grandes concessões, para que os empreendedores locais pudessem participar. Padre João 30 apontou que essa divulgação precisaria ser feita com muita antecedência para que isso chegasse de fato ao conhecimento dos(as) empreendedores(as) locais. Apesar dessa preocupação de que o turismo estivesse nas mãos das comunidades, Marujá 04 relembra uma passagem do Padre João $30 \mathrm{em}$ que se posicionou contra uma família da comunidade que queria fazer uma construção de casa muito superior ao necessário para sua sobrevivência, desrespeitando os acordos coletivos sobre Turismo de Base Comunitária.

Também foram temas de falas do padre João 30 questões relativas às estruturas mínimas de vida das comunidades indígena e caiçaras. As preocupações do clérigo giravam em torno da existência de escola, eletricidade, água e moradia. Outro ponto interessante de defesa das comunidades referiu-se ao MOJAC, em 2006, que recategorizaria parte da área do Parque Estadual do Jacupiranga que abriga-

\footnotetext{
${ }^{14}$ Após a implantação do projeto, a Secretaria de Meio Ambiente do estado produziu um vídeo institucional, apresentando-o: $<$ https://www. youtube.com/watch?v=hM_LbUl-k2w>. Acesso em: jun. 2020.
} 
va comunidade tradicional caiçara, vizinha ao PEIC, como UC do grupo de uso sustentável. As UCs de uso sustentável permitem, em alguma medida, a coexistência de comunidades preexistentes e a conservação da natureza. O SNUC prevê que mosaicos sejam constituídos quando existir "um conjunto de unidades de conservação de categorias diferentes ou não, próximas, justapostas ou sobrepostas, e outras áreas protegidas públicas ou privadas" (Brasil, 2000, art. $26^{\circ}$ ). Apesar de defender essa reconfiguração territorial, Padre João demonstrava-se hesitante de que essa alteração proposta pelo Mosaico fosse suficientemente clara e participativa, pois via como papel premente do Estado auxiliar as comunidades tradicionais nesse sentido.

Quanto aos posicionamentos de Conciliação, segundo Ferreira (2004), ao final dos anos 1990 e início dos anos 2000, iniciou-se nova etapa na gestão das UCs em São Paulo. Um ponto importante desta fase é que assuntos de natureza mais complexa passaram a ser discutidos abertamente, sobretudo pelo fato dos processos de elaboração de planos de manejo das UC paulistas estarem muito atrasadas naquela época. Talvez por isso que essa seja a categoria de maior quantidade de posicionamentos do CPP no Conselho. Não se deve perder de vista, seguindo Max Weber (2002), que a construção de um estatuto político de um movimento social está atrelado à noção de poder, que se acumula. Os conflitos estão no centro das relações sociais e estão enviesados na distribuição do poder. A sociedade e suas complicadas interações são conflituosas. Parte destes conflitos são objeto de negociação constante, que podem ser resolvidos pela própria comunidade no eixo da "rotineirização" das relações cotidianas. A construção da rotina não é desprovida de história e dá sentido e relação com o(a) outro(a).

Dessas questões cotidianas, as principais eram sobre o direito à moradia no interior do PEIC e os direitos dos(as) moradores(as) tradicionais. Em 1998, Padre João 30 contribuiu nas discussões sobre as formas de uso das casas de moradores(as) tradicionais que viviam em casas de veranistas e nas alternativas para que fosse feito esse acordo.

Referente ao episódio em que um morador tradicional foi denunciado por ter realizado uma construção fora das regras estabelecidas no Conselho, Padre João 30 se dispôs a conversar com o responsável pela obra para negociar o prazo de demolição ${ }^{15}$. Posteriormente, o morador compareceu à reunião do Conselho, reconheceu que deveria ter pedido uma nova autorização, mas não o fez. $\mathrm{O}$ Padre mudou de opinião sobre a necessidade de demolição, sobretudo porque o morador já não exercia mais a atividade de pesca. No entanto, Padre João 30 não deixou de alertar o morador sobre o fato de a falta de pedido de autorização ser um desrespeito ao Conselho.

Sobre um caso de conflito de construção supostamente irregular de moradia para membro da comunidade de Pontal de Leste em 2003 e, diante da sugestão de demolição imediata por dano ambiental e envolvimento do Ministério Público, houve uma manifestação por parte do Padre João 30 de que

\footnotetext{
${ }^{15}$ Especificamente nessa época, na Ilha do Cardoso, o Conselho funcionava como um espaço deliberativo, e as decisões eram tomadas com base na Matriz Geral de Planejamento. O documento concedia aos moradores tradicionais os direitos de construção e vetava a mesma prática aos veranistas, fato que fortaleceu a identidade caiçara na Ilha do Cardoso (Rodrigues, 2001). O caso citado dizia respeito a um morador que havia conseguido a autorização para uma reforma, mas além de fazê-la, fez uma segunda construção.
} 
a casa fosse embargada para que a questão fosse resolvida legalmente.

Em 2005, Padre João 30 fez ressalvas de uma proposta de doação de casa de veranista a um morador tradicional. Esse debate teve continuidade em 2006 e, em reunião, os membros do conselho deliberaram sobre qual medida deveria ser tomada sobre as casas de veranistas. O padre João 30 se posicionou a favor da demolição, para seguir o combinado do Parque, mas sugeriu que o material retirado pudesse ser doado aos(às) moradores(as) para que eles construíssem um centro comunitário.

O debate sobre as moradias é intrinsicamente ligado ao que é permitido ou não ao morador tradicional. Em 2001, Padre João 30 sugeriu que fosse feito um comodato entre o Parque e as comunidades. Sustentava sua afirmativa pelo fato do Ibama já ter feito isso, o que demonstrava sua articulação e interesse pelo tema. Apesar disso, surgiram dúvidas sobre o que juridicamente seria o comodato. Deste modo, um advogado e o Padre João 30 comprometeram-se a discutir documentos referentes ao comodato ou cessão que pudessem ser estabelecidos entre o Parque e os(as) moradores(as) tradicionais. Uma proposta resultante desta resolução surgiu nas atas de 2003, quando Padre João 30 sugeriu um encontro sobre o termo de compromisso entre o PEIC e os moradores(as) tradicionais para que não ficassem dúvidas sobre essa demanda ${ }^{16}$ (PEIC, 1998-2010). A discussão sobre o que é ser um(a) morador(a) tradicional ressurgiu em 2005, durante debate sobre a atualização do Plano de Manejo. Foi sugerido pelo clérigo que todos os presentes deveriam fazer um exercício com o objetivo de determinar as características do que seria um(a) morador(a) tradicional, com a intenção de atualizar esse conteúdo/conceito no Plano. Em 2006, o Padre João 30 destacou que a questão de direitos de moradores(as) tradicionais e não moradores(as) já existia há mais de quinze anos e que acreditava que na discussão do plano de manejo pudesse ser encontrada uma solução.

Esteve também como tema nessa categoria de posicionamentos conciliatórios o turismo. Exemplos nessa temática foram a regulação do camping no Marujá (em 1999 e 2000), o envolvimento da comunidade do Ariri ${ }^{17}$ para que fosse beneficiada no arranjo turístico (2000), a questão dos atrativos turísticos para os dias de chuva, quando os(as) turistas em Cananéia e na Ilha do Cardoso tinham poucas opções de atividades de lazer (2004). Posteriormente, em 2005, Padre João 30 contou ao Conselho que tivera uma conversa com uma das lideranças da

\footnotetext{
${ }^{16}$ Parece oportuno considerar que enquanto mediador de conflitos que em que transitava, de uma perspectiva estratégica, muitos espaços de discussão (não apenas junto às comunidades, mas também no âmbito da Unidade de Conservação e políticas correlatas), Pe. João tivesse relativa pressa de colocar em pauta assunto tão emblemático. Como apontado em Loureiro \& Cunha (2008), a linguagem acessível é parte integrante da garantia de discussão democrática no espaço do Conselho Gestor, e essa preocupação do padre não nos passa despercebida. A ameaça à condição de "morador(a) tradicional", entretanto, não deixa de fazer parte do processo de criação de situações que parecem não deixar outras escolhas a não ser a aceitação de um processo muito maior que as partes, algo que Isabelle Stengers (2015) denominou de "alternativas infernais". No fundo, aos(às) moradores(as) tradicionais restava escolher a continuidade ou não em um território que lhes era moradia há gerações. O decreto, nesse sentido, cumpre uma política de Estado bem direcionada que não deixa de ser antidemocrática, no sentido de não ter resolvido tais demandas anteriormente à criação do Parque. Finalmente, seria apropriado situar a relevância dos movimentos sociais, como os que se organizaram no âmbito da Ilha do Cardoso e país afora, justamente por entenderem que a democracia não está fundamentada "em nenhuma natureza das coisas e não é garantida por nenhuma forma institucional” (Rancière, 2014, p. 122). A luta pela democracia não se faz (ou, antes, não apenas) no âmbito institucional.
}

${ }^{17}$ A comunidade caiçara do Ariri fica próxima à Ilha do Cardoso, na parte continental do município de Cananéia. 
aldeia Guarani Mbya para incorporarem o turismo em sua prática. Neste mesmo ano, sugeriu medidas para diminuir a utilização de substâncias ilícitas por parte de turistas que estivessem visitando as dependências do Parque, especificamente na comunidade do Marujá, visto que esse foi um dos problemas apresentados na reunião.

Outro assunto que esteve em debate em 1998 foi a questão dos cães. Segundo Padre João 30, embora fosse importante a regularização da quantidade de cães nos Parques, isso precisaria ser feito com responsabilidade nas comunidades, por se tratar de uma questão cultural. No processo de redução da população de cães no PEIC, o clérigo sugeriu que fossem removidos apenas os cães caçadores e mantidos os cães domésticos, justificado pela cultura das comunidades.

Nota-se também sua atenção para um aspecto relativo à conservação da biodiversidade nativa do local. Em 1998, padre João 30 sugeriu que as casas próximas ao mar no Marujá poderiam ser realocadas para que o corredor de fauna se mantivesse, além de ter levantado a possibilidade de se pensar em outros materiais, que não a madeira, para confecção dos cercos para pesca. Em 2006, durante apresentação do Termo de Ajustamento de Conduta (TAC) sobre as casas de veranistas/irregulares, o qual previa multa, Padre João 30 se manifestou a favor de que o dinheiro fosse usado em conservar aspectos ambientais do Parque.

Essa postura conciliatória se manifesta em sua disposição em contatar as comunidades. Em alguns trechos das atas, como por exemplo, no cadastro dos moradores(as) do PEIC nas comunidades, padre João 30 indicava quem deveriam ser as pessoas contatadas para que isso fosse possível, pois possuía conhecimento das resistências que poderiam ser encontradas (PEIC, 1998-2010). Outro exemplo foi em 2004, quando após conflito entre moradores de uma comunidade, foi proposto pelo Conselho que o agressor fosse punido com a proibição de alugar seu quintal para camping. O Conselho decidiu que seria feita uma comissão para ajudar nesse caso. Padre João 30 e outros membros se manifestaram em entrar nessa comissão e colaborar na resolução do ocorrido.

A partir do Blog, para o Padre João, preservar as UCs equivalia à manutenção da população tradicional, sobretudo do ponto de vista conservacionista (Diegues, 2000a). Embora às vezes não pareça muito claro em sua visão o conflito conceitual entre preservação e conservação, o clérigo estava completamente ciente da discussão que hoje permeia os campos da etnoconservação (Diegues, 2000b). Se alguém - o Estado - declarar um ecossistema como utilidade pública pelo seu valor "ambiental e ecológico", o fato de este ecossistema assim existir devia-se à preservação realizada pela população que ali estava. Diria que o

\begin{abstract}
morador tradicional vive nesse meio ambiente, faz parte dele e tem uma indole de integração, respeito profundo e conservação. Suas atividades extrativistas e de lavoura correspondem a métodos que preservem para os filhos e netos e respeitam os animais e gostam da flora. A natureza é vivida como parte de sua casa e de sua vida e ainda requer um respeito maior porque ela lhe foi dada por Deus para que seja preservada para os demais (No Meio do Povo, 2011).
\end{abstract}

É desta maneira, vendo uma continuidade natural entre o respeito secular e divino da população com o seu meio ambiente, que padre João enxergava a questão da conservação da natureza. Uma área de proteção que prescinde do(a) morador(a) era 
não apenas um local exposto a invasões de todo o tipo, mas uma área de profundo abandono. $\mathrm{O}(\mathrm{a})$ morador(a) "vive integrado[a]" (No Meio do Povo, 2011) no local em que nasce e cresce, criando uma profunda experiência de seu lugar.

\section{Considerações finais}

Este trabalho analisou a atuação do Padre João 30 (que tangencia o CPP) no PEIC e trouxe dados quantitativos e qualitativos que reafirmam a importância que essa instituição ofereceu a partir de sua figura. A experiência retoma o posicionamento da pastoral popular em sua opção preferencial pelos pobres. Cabe o questionamento de qual é o lugar, dentro da Ecologia Política, do "mediador de conflitos". O "mediador de conflitos" está interessado na harmonização das partes. No caso do padre João fica claro que sua proximidade com as comunidades deslocou seu interesse para que as harmonizações fossem mais direcionadas aos(às) caiçaras.

O papel da figura do padre vai um pouco mais além do comum: ele atende "seu povo", mas compreende também sua história. Ele assume o papel do "representante de Deus" na terra, como todo padre. Reza, está preocupado com a condição material e imaterial de sua Igreja e de seu povo. Mas os dados mostram que sua preocupação com a representação da Igreja ("pró-Igreja") é diminuta nos espaços decisórios do Conselho Gestor. Ele parece entender que é parte de sua missão fazer com que a sociedade entenda que o modo de vida caiçara está alinhado àquilo que se espera do povo cristão, por ver na natureza uma manifestação divina de pertencimento. Sua argumentação cria novas possibilidades de análise religiosa na relação com a natureza. Nesse sentido, parece oportuno pensar que outros trabalhos possam ser realizados para entender a complexidade militante dos diversos movimentos que se alternam entre a defesa social e a proteção do meio ambiente, como o caso que apresentamos.

De todo modo, parece evidente que a existência de um "mediador de conflitos" com essas características no contexto analisado tenha sido um fato relevante na harmonização dos conflitos que se instauraram entre os interesses do PEIC e das comunidades tradicionais. Talvez seja possível, ainda, sugerir um posicionamento especial de Pe. João: ele está articulando tanto a comunidade como a natureza. Entende a relevância de uma área protegida, embora seja crítico ao modelo proposto com a gênese do PEIC. Entende também que a preservação do modo de vida caiçara é não apenas culturalmente relevante, mas ecologicamente necessária. Ele ocupa, por assim dizer, uma posição intersticial: compreende os dois lados e media esse território de conflitos a partir de sua mirada ético-religiosa. Pesquisas futuras poderão analisar em que medida o notório decrescimento das participações da pastoral no Conselho do PEIC resultou em maiores dificuldades na solução de conflitos entre as partes. Também pode ser de interesse ao tema analisar em que medida outras religiões que coexistiam no espaço e no tempo tenham tomado para si a possibilidade de intermédio das querelas cotidianas. As formas pelas quais é lembrado padre João 30 parecem indicar que foi ele, também, um formador de possíveis lideranças que, embora não estivessem articuladas no âmbito do CPP, pudessem estar interessadas pelos temas com que o pároco tão bem transitava. Finalmente, a mediação revelou-se como um dispositivo producente na interpretação dos conflitos socioambientais e, portanto, pode ser metodologicamente relevante no âmbito da Ecologia Política. 


\section{Agradecimentos}

Agradecemos a CAPES pela concessão de bolsa de doutorado de dois autores. Agradecemos às comunidades caiçaras da Ilha do Cardoso pelos relatos e à administração do PEIC pela disponibilização das atas de reunião do Conselho. Agradecemos aos(às) organizadores(as) do Blog "No Meio do Povo" pela rica memória coletiva e aos(às) revisores(as) deste artigo pelo empenho em nos orientar no aprimoramento do trabalho.

\section{Material de Pesquisa}

Google Earth Pro. Data das imagens: 13/03/2019. Acesso em: out. 2019.

i3geo. Temas: Unidades de Conservação Brasil. 2019. Disponível em: $<$ https://acervofundiario.incra.gov.br/i3geo/ interface/openlayers.htm>. Acesso em: out. 2019.

Itacuruça/Pereirinha 01. Entrevista com morador(a) tradicional 01 da Comunidade Caiçara Itacuruça/Pereirinha. Parque Estadual Ilha do Cardoso (PEIC), out. 2018.

Itacuruça/Pereirinha 02. Entrevista com morador(a) tradicional 02 da Comunidade Caiçara Itacuruça/Pereirinha. Parque Estadual Ilha do Cardoso (PEIC), out. 2018.

Marujá 04. Entrevista com morador(a) tradicional 04 da Comunidade Caiçara Marujá. Parque Estadual Ilha do Cardoso (PEIC), out. 2018.

No Meio do Povo. Blog dedicado a Jan Van Der Heijden (Pe João 30), 2011. Disponível em: $<$ http://nomeiodopovo. blogspot.com/>. Acesso em: out. 2019.

PEIC - Parque Estadual Ilha do Cardoso. Atas de Reunião $n^{o}$ 01 a n $^{\circ} 141$ do Conselho Consultivo do PEIC, 1998 a 2010.

IBGE - Instituto Brasileiro de Geografia e Estatística. Portal de Mapas do IBGE. Disponível em: $<$ https://portaldemapas. ibge.gov.br/portal.php\#homepage>. Acesso em: out. 2019.

\section{Referências}

Acselrad, H. Ambientalização das lutas sociais - o caso do movimento por justiça ambiental. Estudos Avançados, 24(68), 103-119, 2010.

Adams, C. As populações caiçaras e o mito do bom selvagem: a necessidade de uma nova abordagem interdisciplinar. Revista de Antropologia, 43(1), 145-182, 2000.

Adger, W. N. et al. Advancing a political ecology of global environmental discourses. Development and Change, 32(4), 681-715, 2001.

Arruda, R. S. V. "Populações Tradicionais" e a proteção dos recursos naturais em Unidades de Conservação. In: Milano, M. S. (Org.). Congresso Brasileiro de Unidades de Conservação. Conferências, palestras, resumos, relatórios workshop e moções aprovadas. Curitiba: Unilivre, 1, 262-276, 1997.

Bardin, L. Análise de conteúdo. São Paulo: Grupo Almedina, 70. ed., 2011.

Boff, L. Ecologia: grito da terra, grito dos pobres. São Paulo: Ática, 2. ed.,1996.

Brasil. Lei n. 9.985 de 18 de julho de 2000. Regulamenta o art. 225, $\S 1^{\circ}$, incisos I, II, III e VII da Constituição Federal, institui o Sistema Nacional de Unidades de Conservação da Natureza e dá outras providências. Brasília: DOU $18 / 07 / 2000$

Brasil. Decreto $n^{\circ} 4.340$ de 22 de agosto de 2002. Regulamenta artigos da Lei ${ }^{\circ}$ 9.985, de 18 de julho de 2000, que dispõe sobre o Sistema Nacional de Unidades de Conservação da Natureza - SNUC, e dá outras providências. Brasília: DOU 22/08/2002.

Brasil. Decreto n. $^{\circ} 6.040$ de 7 de fevereiro de 2007. Institui a Política Nacional de Desenvolvimento Sustentável dos Povos e Comunidades Tradicionais. Brasília: DOU 02/07/2007.

Brockington, D.; Duffy, R.; Igoe, J. Nature unbound. Conservation, capitalism and the future of protected areas. London and Sterling: Earthscan, 2008.

Brulle, R. J. Environmental Discourse and Social Movement 
Organizations: A Historical and Rhetorical Perspective on the Development of U.S. Environmental Organizations. Sociological Inquiry, 66(1), 58-83, 1996.

Colchester, M. Resgatando a natureza: comunidades tradicionais e áreas protegidas. In.: Diegues, Antônio Carlos. Etnoconservação: novos rumos para a proteção da natureza nos trópicos. São Paulo: Annablume, 2000.

Conselho Pastoral dos Pescadores. Acordos de pesca: sistematização a partir da experiência de Aparecida do Rio Puru (município de Prainha) Baixo Amazonas/Pará. Brasília, 2017. Disponível em: < http://www.cppnacional.org. br/publicacao/acordos-de-pesca-sistematiza $\% \mathrm{C} 3 \% \mathrm{~A} 7 \%$ C3\%A3o-da-experi\%C3\%AAncia-de-aparecida-do-rio-puru-baixo-amazonas>. Acesso em: nov. 2020.

Consema - Conselho Estadual de Meio Ambiente. Deliberação 26/95 da $103^{a}$ Reunião Ordinária do Plenária do Consema. São Paulo: DOESP de 14/12/1995.

Diegues, A. C. S. Pescadores, camponeses e trabalhadores do mar. São Paulo: Ática, 1983.

Diegues, A. C. S. Diversidade biológica e culturas tradicionais litorâneas: $\mathrm{O}$ caso das comunidades caiçaras. Série de documentos e relatórios de pesquisa. São Paulo: NUPAUB, (5), 1988.

Diegues, A. C. S. Conhecimento e manejo tradicionais. Ciência e biodiversidade. São Paulo: NUPAUB-USP, 2000a.

Diegues, A. C. S. Etnoconservação: novos rumos para a conservação da natureza. São Paulo: Annablume; Hucitec; NUPAUB-USP, 2. ed.,2000b.

Dowie, M. Refugiados da conservação. Tradução de Antônio Carlos Diegues. Orion Magazine, São Paulo, (4), 2006.

Dudley, N. (Org.). guidelines for applying protected area management categories. Gland, Switzerland: IUCN, 2008.

Dupuy, J.-P. Introdução à crítica da ecologia política. Rio de Janeiro: Civilização Brasileira, 1980.

Dussel, E. Teologia da libertação: um panorama de seu desenvolvimento. Petrópolis: Vozes, 1999.

Elmhirst, R. Introducing new feminist political ecologies. Geoforum, Themed Issue: New Feminist Political Ecologies, 42(2), 129-132, 2011.
Ferreira, L. C. Dimensões Humanas da Biodiversidade: mudanças sociais e conflitos em torno de áreas protegidas no Vale do Ribeira, SP, Brasil. Ambiente \& Sociedade, 7(1), 47-66, 2004.

Fox, V. P. P.; Callou, A. B. F. Estratégias de comunicação do Movimento Nacional dos Pescadores do Brasil. Razón y Palabra, 17(84), 639-666, 2013.

Fox, V. P. P.; Efken, K. H. O discurso de resistência do Movimento dos Pescadores e Pescadoras Artesanais do Brasil. Policromias - Revista de Estudos do Discurso, Imagem e Som, 4(2), 237-271, 2019.

Frank, A. G. Acumulação dependente e subdesenvolvimento: repensando a teoria da dependência. São Paulo: Brasiliense, 1980.

Grzybowski, C. Caminhos e descaminhos dos movimentos sociais no campo. Petrópolis: Vozes; FASE, 3. ed.,1991.

Gutiérrez, G. A força histórica dos pobres. Tradução de Álvaro Cunha. Petrópolis: Vozes, 1981.

Jatobá, S. U. S.; Cidade, L. C. F.; Vargas, G. M. Ecologismo, ambientalismo e ecologia política: Diferentes visões da sustentabilidade e do território. Sociedade e Estado, 24(1), 47-87, 2009.

Latour, B. Políticas da natureza: como fazer ciência na democracia. Tradução de Carlos Aurélio Mora De Souza. Bauru, SP: EDUSC, 2004.

Leff, E. Epistemologia ambiental. Tradução de Sandra Valenzuela. São Paulo: Cortez, 2. ed., 2002.

Leff, E. El fuego de la vida: Heidegger ante la cuestión ambiental. Ciudad de México: Siglo Veintiuno Editores, 2018.

Libanio, J. B. O que é pastoral? São Paulo: Brasiliense, 1982.

Loureiro, C. F. B.; Azaziel, M.; Franca, N. Educação ambiental e conselho em unidades de conservação: aspectos teóricos e metodológicos. Rio de Janeiro: Ibase; Instituto TerrAzul; Parque Nacional da Tijuca, 2007.

Loureiro, C. F. B.; Cunha, C. C. Educação ambiental e gestão participativa de unidades de conservação: elementos para se pensar a sustentabilidade democrática. Ambiente \& Sociedade, 11(2), 237-253, 2008. 
Loureiro, C. F. B.; Layrargues, F. P. Ecologia política, justiça e educação ambiental crítica: perspectivas de aliança contra-hegemônica. Trabalho, Educação e Saúde, 11(1), 53-71, 2013.

Löwi, M. Marxismo e cristianismo na América Latina. Lua Nova: Revista de Cultura e Política, (19), 5-21, 1989.

Mattos, S. M. G.; Wosciechowski, J. M.; Caldeira, F. G. Iluminando as capturas ocultas - ICO. A pesca artesanal costeira no Brasil: um estudo de caso, 2020. Disponível em: <https://spark.adobe.com/page/tONM9fbNtuvuj/>. Acesso em: nov. 2020.

Martínez Alier, J. O ecologismo dos pobres. Tradução de Francisco Mendonça. Revista Raega - O Espaço Geográfico em Análise, 1, 7-21, 1997.

Martínez Alier, J. O ecologismo dos pobres: conflitos ambientais e linguagens de valoração. Tradução de Maurício Waldman. São Paulo: Contexto, 2007.

Martins, G. A.; Theóphilo, C. R. Metodologia da investigação científica para ciências sociais aplicadas. São Paulo: Editora Atlas S.A., 2. ed., 2009.

Moaes, E. T. Tradição, religiosidade e turismo: o ritual da bandeira do divino em Cananéia. Caderno de Estudos e Pesquisas do Turismo, 2, 43, 2013.

Nobre, M.; Amazonas, M. C (Orgs.). Desenvolvimento sustentável: a institucionalização de um conceito. Brasília: Ed. IBAMA, 2002.

Perani, C. Pastoral popular e movimentos sociais. Cadernos do CEAS: Revista crítica de humanidades, (119), 13-22, 1989.

Pimenta, P. P. A trama da natureza: organismo e finalidade na época da ilustração. São Paulo: Editora Unesp, 2018.

Pimentel, M. A. S.; Ribeiro, W. C. Populações tradicionais e conflitos em áreas protegidas. Geousp - Espaço e Tempo (Online), 20(2), 224-237, 2016.

Porto-Gonçalves, C. W. Os (des) caminhos do meio ambiente. 2. ed. São Paulo: Contexto, 1990.

Porto-Gonçalves, C. W. A ecologia política na América Latina: reapropriação social da natureza e reinvenção dos territórios. Revista Internacional Interdisciplinar INTER- thesis, 9(1), 16-50, 2012.

Prado, D. M.; Nunes, M. Os Caiçaras em Áreas Protegidas. In: Diegues. A.C.S. Enciclopédia Caiçara: História e memória caiçara. São Paulo: NUPAUB - USP, 4, 387-395, 2005.

Ramalho, C. W. N. O sentir dos sentidos dos pescadores artesanais. Revista de Antropologia, 54(1), 315-352, 2011.

Ramalho, C. W. N. A desnecessidade do trabalho entre pescadores artesanais. Sociologias, (38), 192-220, 2015.

Ramalho, C. W. N; Santos, A. P. Por mares revoltos: a mediação política do Conselho Pastoral dos Pescadores (1968-2018). Revista de Economia e Sociologia Rural, 58(1), 1-22, 2020.

Ramos, E. B.; Gallo, J.; Verrone, V. M. A. Áreas da região lagunar Cananéia-Iguape suscetíveis de exploração pesqueira segundo diversos tipos de tecnologia: I - Pesca com cerco fixo. Boletim do Instituto Oceanográfico, 29(2), 329-335, 1980.

Rancière, J. $O$ ódio à democracia. Tradução de Mariana Echalar. São Paulo: Boitempo, 2014.

Rios, K. A. N. Conflitos e resistência: comunidades tradicionais pesqueiras da Bahia. Cadernos do CEAS: Revista crítica de humanidades, n. 237, 347-364, 2016.

Rodrigues, C. L. Limites do Consenso: territórios polissêmicos na mata atlântica e a gestão ambiental participativa. São Paulo, Tese (Doutorado em Geografia) - USP, 2001.

Sá-Silva, J. R.; Almeida, C. D.; Guindani, J. F. Pesquisa documental: pistas teóricas e metodológicas. Revista Brasileira de História \& Ciências Sociais, 1(1), 2009.

Sader, E. Quando novos personagens entraram em cena: experiências e lutas dos trabalhadores da Grande São Paulo, 1970-1980. Rio de Janeiro: Paz e Terra, 2. ed., 1995.

Santilli, J. F. R. Socioambientalismo e novos direitos: proteção jurídica à diversidade biológica e cultural. São Paulo: Editora Peirópolis, 2005.

Santos, T. A teoria da dependência: balanços e perspectivas. Rio de Janeiro: Civilização Brasileira, 2000.

São Paulo. Decreto $n^{\circ} 40.319$. Dispõe sobre a criação do Parque Estadual da Ilha do Cardoso, em Cananéia. DOESP 
de 03/07/1962.

Sassen, S. Expulsões: brutalidade e complexidade na economia global. Tradução de Angélica Freitas. Rio de Janeiro: Paz e Terra, 2016.

Schröter, B.; Sessin-Dilascio, K.; Meyer, C.; Matzdorf, B.; Sattler, C.; Meyer, A.; Giersch, G; Jericó-Daminello, C.; Wortmann, L. Multi-level governance through adaptive co-management: Conflict resolution in a Brazilian state park. Ecological Processes, 3(1), 1-13, 2014.

Seidl, E.; Neris, W. S. Catolicismo impuro: politização e transgressões da fronteira do religioso. Política \& Sociedade, 16(37), 252-285, 2017.

Serbin, K. P. Padres, celibato e conflito social: uma história da Igreja católica no Brasil. São Paulo: Companhia das Letras, 2008.

Sessin-Dilascio, K. Cogestão adaptativa e capital social na gestão de unidades de conservação integrais brasileiras com comunidades: o estudo de caso do Parque Estadual da Ilha do Cardoso e da comunidade do Marujá. São Paulo, Dissertação (Mestrado em Ciência Ambiental) - USP, 2014.

Silva, A. L. F. Onde os direitos ambientais sobrepõem direitos humanos na mata atlântica brasileira: estudo a respeito da diversidade cultural em comunidades tradicionais sobrepostas por unidades de conservação no Vale do Ribeira, SP. Piracicaba, Dissertação (Mestrado em Ciências) - USP, 2014.
Silva, A. P. Pesca artesanal brasileira. Aspectos culturais, históricos, institucionais e prospectivos. Palmas: Embrapa Pesca e Agricultura, 2014.

Simondon, G. Do modo de existência dos objetos técnicos: introdução. Laboreal, 14(1), 69-7, [1969] 2018. Disponível em: http://www.scielo.mec.pt/pdf/lab/v14n1/v14n1a09.pdf

Stengers, I. No tempo das catástrofes. Tradução de Eloísa Araújo Ribeiro. São Paulo: Cosac Naify, 2015.

Stott, P.; Sullivan, S. Political ecology: science, myth and power. London: Arnold; New York: Oxford University Press Inc., 2000.

Tomás, A. F.; Santos, G. (Orgs.) Conflitos socioambientais e violações de direitos humanos em comunidades tradicionais pesqueiras no Brasil. Conselho Pastoral dos Pescadores: Brasília, 2016.

Uwe, F. Introdução à pesquisa qualitativa. Tradução de Joice Elias Costa. Porto Alegre: Artmed, 3. ed., 2009.

Waldman, M. Ecologia na perspectiva dos trabalhadores. Tempo e Presença, p. 4-5, 1988.

Waldman, M. Ecologia e lutas sociais no Brasil. São Paulo: Contexto, 2. ed., 1994.

Weber, M. Conceitos básicos de sociologia. Tradução de Rubens Eduardo Ferreira Frias e Gerald Georges Delaunay. São Paulo: Centauro, 2002.

Yamaoka, J. G.; Cardoso, T. M.; Denardim, V. F.; Alves, A. R. A comunidade caiçara da Enseada da Baleia e a sua luta pelo território - Cananéia (SP). Guaju, 5(1), 138-165, 2019. 